\title{
내분비계장애물질의 생태독성평가를 위한 표준시험법 비교연구 A Comparative Study of Standard Methods for Assessing Ecotoxicity of Endocrine Disrupting Chemicals
}

\author{
곽진일 · 최영설 · 문종민 · 김도경 $\cdot$ 안윤주 $^{\dagger}$ \\ Jin Il Kwak $\cdot$ Rongxue Cui · Jongmin Moon · Dokyung Kim • Youn-Joo An ${ }^{\dagger}$ \\ 건국대학교 환경보건과학과 \\ Department of Environmental Health Science, Konkuk University
}

(Received January 11, 2017; Revised February 14, 2017; Accepted March 3, 2017)

\begin{abstract}
Endocrine disrupting chemicals (EDCs) interfere with endocrine system in organisms, and have different mode of actions compared to conventional chemicals. Therefore, EDCs specific ecotoxicity tests and assessments have been globally developed by some organizations such as OECD, ASTM, and USEPA. In Korea, researches on EDCs and monitoring of EDCs in domestic environments were also continued. However, Korean ecotoxicity test guidelines for EDCs are not suggested till date. The purpose of this study is to review and analyze international ecotoxicity test guidelines for EDCs and the compare ecotoxicity methods and toxicity endpoints among standard test guidelines. We found that there are very limited EDCs specific soil ecotoxicity test guidelines (only in ASTM) compared to aquatic ecotoxicity test guidelines. Currently, fish, amphibian, waterflea, copepoda, earthworm, white worm, springtail, nematode, mite, and midge are suggested as standard ecotoxicity test species for EDCs. Reproduction, hormones, growth, vitellogenin, sex retio and development were proposed as endpoints for EDCs ecotoxicity. This study provided the comparison of EDCs specific ecotoxicity methods and endpoints between standard test guidelines, and suggested the further research to develop the method for assesseing ecotoxicity of EDCs.
\end{abstract}

Key Words : Endocrine Disrupting Chemicals, Ecotoxicity, Toxicity Endpoints

요약 : 내분비계 장애물질 (EDCs)은 생물체내에 유입되면 내분비계의 정상적 기능을 방해하는 특징이 있으며, 일반화학물 질과는 다른 독성기전을 보이기 때문에 기존의 생태독성기법과 달리 EDCs만의 독성을 평가하기 위한 생태독성기법 및 독성 종말점의 개발을 위한 연구가 필요하다. $\mathrm{OECD}, \mathrm{ASTM}$ 및 $\mathrm{USEPA}$ 와 같은 신뢰성 있는 국제기관에서는 $\mathrm{EDCs}$ 의 생태독성기 법들을 제안하고 있는 상황이다. EDCs가 유해성이 알려진 만큼 국내에서도 EDCs관련 정부지원 사업이 일부 EDCs에 대해 사업장에의 배출량, 환경매체에서 검출농도를 지속적으로 모니터링하고 있으며, EDCs관련 연구들이 보고되고 있다. 그러나 국내에는 $\mathrm{EDCs}$ 를 대상으로 하는 생태독성기법이 부재한 상황이다. 본 연구에서는 국외 $\mathrm{EDCs}$ 의 생태독성기법을 조사 및 분 석하여 제안된 생물종과 독성종말점의 종류 및 시험조건 파악하고자 하였다. 그 결과, ISO에서는 아직 EDCs 생태독성기법을 따로 제안하고 있지 않은 상태이며, OECD, ASTM, USEPA에서만 수서생물종인 어류 양서류, 물벼룩 및 요각류, 토양생물종 인 지렁이, 애지렁이, 톡토기, 진드기, 토양선충, 그리고 퇴적물서식종인 지렁이와 깔따구에 대한 EDCs 평가기법이 제시되어 있고, 생식, 호르몬, 성장, 비탈로제닌, 성비 및 발달 등과 관련된 독성종말점으로 제안되어 있었다. 결론적으로 EDCs 대상의 생태독성 평가방법은 매우 제한적이며, 생태독성 기법 개발 및 독성종말점을 개발하기 위한 연구가 필요한 것으로 판단된다. 주제어 : 내분비계장애물질, 생태독성, 독성종말점

\section{1. 서 론}

내분비계 장애물질(Endocrine disrupting chemicals, EDCs) 이란 “내분비계의 정상적인 기능을 방해하는 물질로 환경 으로 배출된 물질이 체내에 유입되어 마치 호르몬처럼 작 용한다고 하여 환경호르몬으로 불리기도 하는 물질"1)이다. $\mathrm{EDCs}$ 에 노출될 경우 인간뿐만 아니라 생태계 모든 생물종 에 위험할 수 있기 때문에, ${ }^{1,2}$ 국제적으로 $\mathrm{EDCs}$ 에 대한 문 제인식을 하고 관련 연구 및 규제가 이뤄지고 있다.

우리나라의 경우 환경부에서 관련 연구로써 “내분비계장애 물질 조사- 연구사업(VI)", “물ㄹ환경종합평가방법 개발 조사 연구(III)"(4) 등을 수행한 바 있으며, “수계 유출가능성이 있는 유해화학물질 분류화,"2)에서는 수계유출 가능성별 우선순위
물질 목록 도출시 세계야생보호기금과 환환경부의 환경자료 집 $^{1)}$ 에 근거하여 유해성을 파악한바 있다. 최근에는 2015년도 의 "EDCs 통합적 위해평가 및 수용체 중심의 통합적 위해관리 방안 구축", 2016년의 "EDCs 통합위해관리를 위한 한국형 환경 및 생태 유해성 평가 기술 개발"과 같이 환경호르몬으로부터 인체 및 생태 보호를 위한 연구들이 활발히 진행되고 있다. 국내환경을 보호하기 위한 매체별(수질, 토양) 기준의 경 우 EDCs 특성이 있는 일부 물질들이 기준들에 포함되어 있 는 상황이다. 다만, 각 법에서 $\mathrm{EDCs}$ 로 특정하지 않고, 다 른 물질들과 동일한 잣대로 관리하고 있다. 수질 및 수생태 계 보전에 관한 법률에 근거하여 특정수질유해물질로 EDCs 특성이 있는 것으로 알려진 물질인 polychlorinated biphenyl, di(2-ethylhexyl) phthalate, lead, mercury, cadmium가 지정되 
어 있고, 수질 및 수생태계 보전에 관한 법률 시행규칙의 수 질오염물질 목록에도 polychlorinated biphenyl, di(2-ethylhexyl) phthalate, lead, mercury, cadmium이 포함되어 있다. 환경정 책기본법에서는 사람의 건강보호를 위한 수질 기준에 근거 하여 polychlorinated biphenyl, di(2-ethylhexyl) phthalate, hexachlorobenzene, lead, mercury, cadmium을 관리하고 있 으며, 토양오염우려기준에서는 polychlorinated biphenyl, lead, mercury, cadmium을 관리하고 있다.

또한 국내에서는 11 종의 내분비계 장애추정물질(4,4'-Bisphenol A, 4-tert-octylphenol, branched 4-nonylphenol, nonylphenol, di(2-ethylhexyl) adipate, di(2-ethylhexyl) phthalate, mancozeb, benomyl, amitrole, carbaryl, permethrin)에 대해 사업장에서 환경매체로의 연간 배출량, 자가매립량, 및 위탁처리량에 대한 정보를 주기적으로 보고하도록 하고 있다. ${ }^{5)}$ 국내 수 계 모니터링의 경우 환경부 수질측정망을 통해 $\mathrm{EDCs}$ 특 성이 있는 것으로 알려진 물질인 polychlorinated biphenyl, di(2-ethylhexyl) phthalate, hexachlorobenzene, cadmium, lead, mercury을 대상으로 연 1회-12회 모니터링 하고 있다. ${ }^{6,7)}$ 또한 퇴적물 측정망을 통해 하천의 퇴적물에서 $\mathrm{EDCs}$ 특성이 있 는 것으로 알려진 cadmium, lead, mercury이 포함되어 연 1회 모 니터링하고 있으며, 호소 퇴적물에서 polychlorinated biphenyls 10동족체(Chlorobiphenyl, Dichlorobiphenyl, Trichlorobiphenyl, Tetrachlorobiphenyl, Pentachlorobiphenyl, Hexachlorobiphenyl, Heptachlorobiphenyl, Octachlorobiphenyl, Nonachlorobiphenyl, Decachlorobipheny)와 DDTs 6종(o,p'-DDE, p,p'-DDE, o,p'-DDD, p,p'-DDD, o,p'-DDT, p,p'-DDT)을 연 1회 모니터링하고 있다. ${ }^{6,7)}$

위와 같이 국내에서는 $\mathrm{EDCs}$ 를 대상으로 정부지원 관련연 구 수행 및 환경매체에서의 모니터링이 지속되고 있고, 제한 적이긴 하나 환경매체별 기준이 마련되어 있다. 그러나 아직 국내에서 $\mathrm{EDCs}$ 의 생태독성기법과 관련된 연구가 수행된바 없고, 기법이 구축되지 않은 상황이므로, 본 연구에서는 국 외 $\mathrm{EDCs}$ 관련 생태독성기법을 조사하여 시험조건 및 독성종 말점을 비교하고자 국내 적용 가능성을 검토하고자 하였다.

\section{2. 연구방법}

$\mathrm{EDCs}$ 의 생태독성기법 문헌 수집을 위해 국제기관에서 제시하는 검증된 시험법으로 범위를 설정하였다. 조사기관 은 Organisation for Economic Cooperation and Development (OECD), American Society for Testing and Materials (ASTM), U.S. Environmental Protection Agency (USEPA) 및 International Organization for Standardization (ISO)을 대상으로 하였으 며, 일반물질이 아닌 $\mathrm{EDCs}$ 에 특화된 생태독성기법 존재여 부 확인 및 독성종말점 분석을 수행하였다.

\section{3. 연구결과}

\subsection{OECD}

$\mathrm{OECD}^{8}$ 에서는 시험지침 프로그램(OECD Test Guidelines Programme)을 위한 시험지침 작업반(working group of national coordinators of the test guidelines programme, WNT) 을 운영하여 $\mathrm{EDCs}$ 시험평가 작업을 진행하고 있다. $\mathrm{EDCs}$ 시험평가 작업은 내분비교란물질 시험 및 평가 감독그룹, 생태독성시험 개발그룹, 비동물시험 개발그룹, 포유동물 시 험 개발그룹 4 개의 주요 그룹으로 나뉘어 관리되고 있으며 EDCs 시험평가를 위하여 1996년부터 OECD 시험지침 프 로그램 중 절반에 달하는 시험지침(test guideline, TG)과 기 타 툴(tool)을 개발하였다. 또한 2002년에 EDCs Conceptual Framework (CF)를 제시하였으며 2012년에 업데이트를 하였 다. $\mathrm{CF}^{9}$ 에서는 시험레벨을 5 개 레벨로 나누어 제시하고 있 는데, 레벨 1 에서는 기존 데이터 및 비시험정보 관련 내용 을 포함하고 있으며 레벨 2-5에서는 내분비 메커니즘, 경로, 내분비 관련 부정적인 영향 관련 독성종말점 산출에 적용 가능한 독성시험을 포유류와 비포유류로 나누어 제시하고 있다. 생태독성평가를 위한 독성시험은 비포유류를 이용한 독성기법에 포함되었으며 총 24종의 생태독성시험을 권장 하고 있다. 제시된 생태독성시험 중 현재 사용 가능한 $\mathrm{TG}$ 는 기존에 존재하는 일반물질에 대한 $\mathrm{TG}, \mathrm{EDCs}$ 평가를 위하 여 업데이트한 TG 및 $\mathrm{EDCs}$ 평가만을 위해 개발된 $\mathrm{TG}$ 를 포 함하여 15 건이 있으며, 그 외 9건의 독성시험에 관하여 시 험기법이 계속하여 개발 중인 것으로 확인되었고 관련 내용 은 보고서 또는 $\mathrm{GD}$ 로 제시되어 있다. 개발 중인 시험기법으 로는 물벼룩을 이용한 다세대 평가, ${ }^{9}$ 양서류의 수정란을 이 용한 갑상선 신호 방법, ${ }^{9,10)}$ 연체동물을 이용한 부분 및 전 반 생활사 평가, ${ }^{9,10)}$ 어류 생활사 독성평가, ${ }^{9,11}$ 암컷 큰가시 고기를 이용한 안드로제닉 스크리닝 평가, ${ }^{9,12 ~ 14)}$ 보리새우 생 활사 독성평가, ${ }^{9,10)}$ 어류 부분 생활사에서의 생식율 평가, ${ }^{9,15}$ 요각류를 이용한 생식율 및 발달평가, ${ }^{9,16,17)}$ 가 있다. 또한 $\mathrm{OECD}$ 는 계속하여 $\mathrm{EDCs}$ 에 관하여 연구를 진행하여 문서를 제시하고 있으며 현재 $\mathrm{EDCs}$ 시험 및 평가에 관하여 59건의 리포트가 제시가 되어 있다. ${ }^{18)}$ 한편, $\mathrm{OECD}$ 는 기존에 존재 하는 일반물질에 대한 TG 중 $\mathrm{EDCs}$ 생태독성평가에 적용 가 능한지를 검토하여 기존의 15 건의 TG 중 일부 어류, 양서류, 깔따구, 지렁이, 물벼룩, 톡토기, 애지렁이, 진드기 대상의 $\mathrm{TG}$ 를 $\mathrm{EDCs}$ 평가에 활용 가능 한 것으로 보고하였다."

따라서 $\mathrm{OECD}$ 에서 검증한 $\mathrm{EDCs}$ 생태독성평가 관련 $\mathrm{TG}$ 중 생물종으로는 어류가 4건으로 가장 많았으며 시험매체는 수서 7건, 토양 4건, 퇴적물 4건으로 수생태 독성기법이 가 장 많은 것으로 분석되었다. 독성종말점은 모든 시험지침에 서 생존율과 생식율을 기반으로 하고 있으며 어류와 양서류 를 이용한 TG에서만 $\mathrm{EDCs}$ 관련 특정 독성종말점을 제시 하고 있다(Table 1). 수서매체에서의 독성기법은 어류, 양서 류, 물벼룩을 이용한 7건의 시험기법으로 어류 4건, 양서류 2건, 물벼룩 1건이 있다. 어류 관련 TG는 TG $229,{ }^{19)} \mathrm{TG}$ $230,{ }^{20)} \mathrm{TG} 234,{ }^{21)} \mathrm{TG} 240^{22)}$ 에 제시되어 있다.

TG $229^{19)}$ 는 EDCs 평가 관련 리포트인 No. 109 를 기반으 로 한 어류 급성 생식율 평가 시험법으로 Pimephales promelas; 
Table 1. EDCs specific ecotoxicity test guidelines and test conditions in OECD

\begin{tabular}{|c|c|c|c|c|c|c|c|}
\hline Species & $\begin{array}{c}\text { Test } \\
\text { duration }\end{array}$ & Media & Temperature & Light & Endpoint & Note & Ref. \\
\hline $\begin{array}{l}\text { Pimephalespromelas; } \\
\text { Oryziaslatipes; } \\
\text { Daniorerio }\end{array}$ & $21 d$ & water & $25 / 26 \pm 2^{\circ} \mathrm{C}$ & $\begin{array}{l}\text { 12/16 h light, } \\
540-1000 \text { lux }\end{array}$ & $\begin{array}{l}\text { survival, behaviour, fecundity, } 2 y \text { sex } \\
\text { characteristics, VTG, gnadal histopathology }\end{array}$ & Developed & 19) \\
\hline $\begin{array}{l}\text { Pimephalespromelas; } \\
\text { Oryziaslatipes; } \\
\text { Daniorerio }\end{array}$ & $21 d$ & water & $25 / 26 \pm 2^{\circ} \mathrm{C}$ & $\begin{array}{l}\text { 12/16 h light, } \\
540-1000 \text { lux }\end{array}$ & $\begin{array}{l}\text { survival, behaviour, fecundity, } 2 \text { y sex } \\
\text { characteristics, VTG, oestrogenic, aromatase } \\
\text { inhibition, androgenic activity }\end{array}$ & Developed & 20) \\
\hline $\begin{array}{l}\text { Oryziaslatipes; } \\
\text { Daniorerio; } \\
\text { Gasterostreusaculeatus }\end{array}$ & $60 \mathrm{dph}$ & water & $20 / 25 / 27 \pm 2^{\circ} \mathrm{C}$ & $\begin{array}{l}\text { 12-16 h light, } \\
540-1080 \text { lux }\end{array}$ & $\begin{array}{l}\text { hatching success, survival gross-morphology, } \\
\text { VTG gonadal histology, sex retio }\end{array}$ & Developed & 21) \\
\hline Oryzias latipes & $19 w$ & water & $24-26^{\circ} \mathrm{C}$ & $\begin{array}{l}16 \text { h light, } \\
\sim 150 \text { lux }\end{array}$ & $\begin{array}{l}\text { fecundity, fertility, hatching, growth, survival, } \\
\text { VTG, secondary sex characteristics, external sex } \\
\text { ratio, time of } 1 \text { st spawn, hisropathology (gonad, } \\
\text { liver, kidney) }\end{array}$ & Developed & 22) \\
\hline Xenopus laevis & $21 d$ & water & $22 \pm 1^{\circ} \mathrm{C}$ & $\begin{array}{l}12 \mathrm{~h} \text { light, } \\
600-2000 \text { lux }\end{array}$ & $\begin{array}{l}\text { mortality, development stage, hind limb length, } \\
\text { SVL, wet body weight, thyroid gland histology }\end{array}$ & Developed & 23) \\
\hline Xenopus laevis & $\sim 17 \mathrm{~W}$ & water & $21 \pm 1^{\circ} \mathrm{C}$ & $\begin{array}{l}12 \mathrm{~h} \text { light, } \\
600-2000 \text { lux }\end{array}$ & $\begin{array}{l}\text { mortality, time of NF stage 62, thyroid histology } \\
\text { assessment, growth, liver-somatic index, } \\
\text { genetic/phenotypic sex ratios, histopathology for } \\
\text { gonads, reproduction ducts, kidney and liver and } \\
\text { plasma VTG }\end{array}$ & Developed & 24) \\
\hline Daphnia magna & $21 d$ & water & $18-22^{\circ} \mathrm{C}$ & $\begin{array}{l}\text { 16hlight, } \\
<15-20 \mu E m- \\
2 S-1\end{array}$ & $\begin{array}{l}\text { offspring, mortality, growth, first brood, broods } \\
\text { size, aborted broods, male neonates, ephippia, } \\
\text { intrinsic rate }\end{array}$ & Updated & 29) \\
\hline Enchytraeus albidus & $42 d$ & soil & $20 \pm 2^{\circ} \mathrm{C}$ & $\begin{array}{l}16 \text { h light, } \\
400-800 \text { lux }\end{array}$ & fecundity, mortality, behavioural change & Existed & 31) \\
\hline $\begin{array}{l}\text { Eiseniafetida; } \\
\text { Eiseniaandrei }\end{array}$ & $56 d$ & soil & $20 \pm 2^{\circ} \mathrm{C}$ & $\begin{array}{l}16 \text { h light, } \\
400-800 \text { lux }\end{array}$ & $\begin{array}{l}\text { mortality, weight, reproduction, behavioural } \\
\text { change }\end{array}$ & Existed & 32) \\
\hline $\begin{array}{l}\text { Hypoaspis (Geolaelaps) } \\
\text { aculeifer }\end{array}$ & $14 d$ & soil & $20 \pm 2^{\circ} \mathrm{C}$ & $\begin{array}{c}16 \text { h light, } \\
400-800 \text { lux }\end{array}$ & reproduction, mortality, behavioural change & Existed & 33) \\
\hline $\begin{array}{l}\text { Folsomiacandida; } \\
\text { Folsomiafimetaria }\end{array}$ & $21 / 28 d$ & soil & $20 \pm 1^{\circ} \mathrm{C}$ & $\begin{array}{l}12 \mathrm{~h} \text { light, } \\
400-800 \text { lux }\end{array}$ & reproduction, mortality, behavioural change & Existed & 34) \\
\hline Chironomus sp. & $20-65 d$ & sediment & $20 / 23-25^{\circ} \mathrm{C}$ & $\begin{array}{l}16 \mathrm{~h} \text { light, } \\
500-1000 \text { lux }\end{array}$ & emergence, growth, survival & Existed & 35) \\
\hline Chironomus sp. & $20-65 d$ & sediment & $20 / 23-25^{\circ} \mathrm{C}$ & $\begin{array}{l}16 \text { h light, } \\
500-1000 \text { lux }\end{array}$ & emergence, growth, survival & Existed & 36) \\
\hline Chironomus sp. & $44 / 100 \mathrm{~d}$ & sediment & $20 / 23 / 25 \pm 2^{\circ} \mathrm{C}$ & $\begin{array}{l}16 \text { h light, } \\
500-1000 \text { lux }\end{array}$ & $\begin{array}{l}\text { reproduction, development rate, sex retio, } \\
\text { mortality, behavioural change, No. of egg ropes, } \\
\text { fertility of egg ropes }\end{array}$ & Developed & 37) \\
\hline Lumbriculus variegatus & $28 d$ & sediment & $20 \pm 2^{\circ} \mathrm{C}$ & $\begin{array}{l}16 \mathrm{~h} \text { light, } \\
100-500 \text { lux }\end{array}$ & $\begin{array}{l}\text { mortality, biomass, reproduction, behavioural } \\
\text { change }\end{array}$ & Existed & 38) \\
\hline
\end{tabular}

Oryzias latipes; Danio rerio 3가지 시험종을 이용하여 어류 생식율에 대하여 시험법으로 암수컷 성체를 21 일간 유수식 으로 노출시켜 생존, 거동, 생식, 2차 성징 특성, 비텔로제닌 (vitellogenin, VTG), 생식선 조직병리를 독성종말점으로 사 용하였다. TG $230^{20)}$ 은 리포트 No $76,77,91,92$ 등의 EDCs 평가 관련 리포트가 제시되어 있으며 어류 단시간 노출을 통하여 에스트로제닉, 안드로제닉 활성과 아로마타제 저해 를 평가하는 스크리닝 시험법이다. 이때 시험종은 Pimephales promelas; Oryzias latipes; Danio rerio 성체를 제안하였으며 유수식 환경에서 21 일간 노출하여 생존, 거동, 2차 성징, VTG 를 독성종말점으로 제시하였다. TG $234^{21)}$ 는 어류 성적 발달 에 관한 시험법으로 Oryzias latipes, Danio rerio, Gasterostreus aculeatus 의 수정란을 사용하여 유수식 혹은 반지수식에서 $60 \mathrm{dph}$ (days post-hatch)간 진행하였으며 독성종말점은 부 화율, 형태변화, VTG, 성비(sex ratio)를 측정하였다. TG 240 22$)$ 은 Oryzias latipes를 이용한 한세대 이상 생식율 평가 시험 법으로 유수식에서 한쌍의 $12 \mathrm{wpf}$ (weeks post fertilization) 암수컷을 노출하였으며 태어난 수정란 (F1)을 재노출하여 F2 가 부화할 때까지 진행하였다. 시험기간은 19주이며 독성종 말점은 F0의 생식율; F1의 부화율, 생존 (0-4 wpf, 4-9 wpf, 9-15 wpf), 성장, 2차 성징 특성, $\mathrm{VTG}$, 생식선 발달, 생식, 산 란까지의 기간, 조직병리학; F2의 부화율을 측정하였다. 양 서류를 이용한 독성기법는 TG 231, ${ }^{23)} \mathrm{TG} 241^{24)}$ 로 시험은 수 서환경에서 진행되었다. 
TG $231^{23)}$ 은 EDCs 관련 리포트 No $76,{ }^{25)} 77,{ }^{26)} 91,{ }^{27)} 92^{28)}$ 등이 있으며 Xenopus laevis를 이용한 변태(metaorphosis) 평 가 시험기법으로 유충(larvae)을 이용하여 유수식 또는 반 지수식에서 총 21 일간 진행되었으며 생존, 발달단계, 뒷다 리 길이, 콧구멍 길이, 무게, 갑성선 조직학을 독성종말점 으로 사용하였다. TG 241 ${ }^{24)}$ 는 Xenopus laevis를 이용한 성 장 및 발달단계 평가 독성기법으로 유수식에서 최대 14 주 간 진행하여 개체의 생존, 생식, NF 62단계에 도달하는 시 간, 갑상선 조직병리, 성장, 간 수치, 유전적/표현형 성비, 생식선 조직병리, 신장과 간 및 플라스마 VTG를 독성종말 점으로 제시하고 있다.

물벼룩 독성기법은 $\mathrm{TG} 211^{29}$ 로 $\mathrm{EDCs}$ 평가에 적용하기 위하여 EDCs 관련 리포트 No $93^{30}$ 을 기반으로 2012년에 업데이트를 하였으며 ${ }^{8)}$ Daphnia magna를 이용한 생식율 평 가 시헙법으로 21 일간 태어난 지 $24 \mathrm{~h}$ 미만 어린 개체를 노 출하여 유수식 또는 반지수식으로 진행되며 독성종말점은 생존, 성장, 생식, 첫배 생산시간, 배반복, 낙태된 배수, 수 컷 개체 생성을 제시하고 있다.

토양에서는 애지렁이, 지렁이, 진드기, 톡토기를 이용한 총 4건의 시험기법으로 각각 $\mathrm{TG} 220,{ }^{31)} \mathrm{TG} 222,{ }^{32)} \mathrm{TG} 226^{33)}$ 및 TG $232^{34)}$ 에 제시되어 있다. TG $220^{31}$ 은 Enchytraeus albidus 성체를 이용한 생식율 평가 독성기법으로 시험기간 은 총 42 일로 성체 제거 전 후로 각각 21 일간 노출하여 성체 의 생존, 생식, 거동을 독성종말점으로 제시하였다. TG 222 $2^{32)}$ 는 Eisenia fetida와 Eisenia andrei 성체를 시험종으로 사용 하여 지렁이 생식율 평가 시험법이며 시험기간은 총 56 일로 성체 제거 전 후 각각 28 일간 노출하여 성체의 생존, 생식, 거동을 독성종말점으로 사용하고 있다. TG $226^{33)}$ 은 육식성 진드기인 Hypoaspis (Geolaelapa) aculeifer의 암컷 성체를 이용하여 생식독성을 평가한 시험법으로 시험기간은 14 일로 독성종말점은 생존, 생식을 측정하였다. TG 23224)는 Folsomia candida와 Folsomia fimetaria를 이용하여 생식율 평가를 위 한 시험기법이다. Folsomia candida는 9-12일 개체를 사용하 여 28일간 노출하고 Folsomia fimetaria는 23-26일 개체를 사 용하여 21 일간 노출하며 독성종말점은 모두 생존과 생식을 제시하였다.

퇴적물에서는 총 4 건의 시험기법으로 깔따구 3 건과 지렁 이 1건으로 각각 TG $218,{ }^{35)} \mathrm{TG} 219,{ }^{36)} \mathrm{TG} 233^{37)}$ 및 $\mathrm{TG}$ $225^{38)}$ 에 제시되었다. TG 218-21953, 는 Chironomus riparius, Chironomus tentans, Chironomus yoshimatui 1 령기 유생을 이용 한 독성시험기법으로 노출기간은 C. riparius와 C. yoshimatui는 28 일, C. tentans는 65 일이며 유수식 또는 반지수식에서 시 험을 진행하며 독성종말점은 생존, 개체출현율(emergence), 개체출현까지의 시간, 알 무게를 사용하였다. TG $233^{37)}$ 은 Chironomus riparius, Chironomus dilutus, Chironomus yoshimatui 1 령기 유생을 이용한 생활사 독성평가 시험기법으로 시험기 간은 $\mathrm{F} 1$ 세대까지 진행되어 $\mathrm{F} 0$ 및 $\mathrm{F} 1$ 노출기간이 C. riparius 와 C. yoshimatui는 최대 28일이며 C. dilutus는 최대 65일 이다. 독성종말점은 F0 및 $\mathrm{F} 1$ 세대의 암수컷 개체출현, 성비,
생존율, 거동, 생식율을 평가하였다. TG $225^{38)}$ 는 Lumbriculus variegatus 성체를 이용한 독성평가 시험기법으로 28 일간 노출 후 생존, 무게, 생식, 거동을 독성종말점으로 사용하 였다.

\subsection{ASTM}

ASTM은 1999년에 "Environmental Toxicology and Risk Assessment: Standardization of Biomarkers for Endocrine Disruption and Environmental Assessment ${ }^{399}$ 를 출판하며 $\mathrm{EDCs}$ 생태독성평가 관련 문서를 제시하였다. 본 문서에는 무척추동물과 척추동물을 이용한 $\mathrm{EDCs}$ 스크리닝 평가 방 법, 체외에서의 내분비 시험방법, 산업적 관점에서의 내분 비 스크리닝 방법에 관한 29건의 문서가 포함되어 있으며, 독성 및 위해성평가를 위한 생물지표 종말점을 중점으로 제시하였다. 여기에는 생화학적, 발전단계별, 거동 및 내분 비 지표가 포함되어 있다. 그 중 $\mathrm{EDCs}$ 에 대한 생태독성기법 관련 문서는 총 19건(어류 7건, 무척추동물 1건, 패류 1건, 원생동물 1 건, 해양갑각류 2 건, 토양선충 1 건)이었으며, 그 외에 $\mathrm{EDCs}$ 독성평가를 위한 갑상선 기능 평가, 에스트로 겐 활성 평가, 뇌-뇌하수체-고환에서의 생식율 평가, EROD 효소활성 평가, 유세포분석기(flow cytometry)를 이용한 세 포분석, 현장샘플을 이용한 독성평가 등의 기법을 제시하 였다. 생태독성과 관련하여 어류 관련 시험기법이 가장 많 았으며, 퇴적물에서는 조개를 이용한 생존율 평가가 포함되 어 있고, 토양매체에서는 토양선충을 이용한 생식율 평가만 이 있는 것으로 확인되었다(Table 2).

어류를 이용한 독성평가는 다양한 종을 이용하여 유전자분 석부터 개체독성평가를 진행하였다. Cyprinodon variegatus를 이용한 독성기법은 시험물질을 주입하고 4일 후 추가주입 후 VTG mRNA, 에스트로겐 리셉터 mRNA 평가하였다. Oryzias latipes를 이용한 독성기법에서는 in vitro는 3 시간 노출, in vivo는 10 일간 노출 후 뇌의 아로마타제 활성(aromatase activity)을 평가하였다. Oreochromis mossambicus를 이용한 독 성기법은 시험물질에 28 일 노출 후 성비, 무게, 간 무게, 고 화 무게, 뇌하수체 무게 등을 독성종말점으로 제시하였다. Orconectes rusticus를 이용한 독성기법은 $7 \mathrm{~d}$ 노출 후 생존 율과 거동을 평가하였으며 Oncorhynchus mykiss를 이용한 독성기법은 $96 \mathrm{~h}$ 노출 후 거동, 단백질함량 및 콜린에스테 라제 활성을 평가하였다. Lepomis macrochirus를 이용한 독 성기법은 실험실에서 30 일 노출 후 생존, 성장, 유영상태, 개체간 충돌횟수, 먹이효율, 공격성 등을 독성종말점으로 제 시하였고 메조코즘(mesocosm) 환경에서는 56일 노출 후 생 존, 성장, 무게, 생식율을 평가하였다. Oreochromis niloticus 를 이용한 독성기법은 각각 4개월, 7 개월, 치사 전까지 노 출하여 생존 및 시험물질의 축적을 평가하였다.

무척추동물을 이용한 독성기법으로는 ASTM E1193-87 $7^{40)}$ 을 기반으로 한 물벼룩 독성평가 및 ASTM E1191-90 $0^{41}$ 을 기반으로 한 새우류 독성평가를 제시하고 있는데 물벼룩은 21 일, 새우류는 28 일 만성노출 후 성장, 탈피, 발달, VTG, 
Table 2. EDCs specific ecotoxicity test guidelines and test conditions in ASTM ${ }^{39)}$

\begin{tabular}{|c|c|c|c|}
\hline Species & Test duration & Media & Endpoint \\
\hline Daphnia & $21 d$ & \multirow{2}{*}{ water } & \multirow{2}{*}{$\begin{array}{l}\text { growth, molting, parthenogenetic development, VTG, lipid analyses, steroid } \\
\text { hormone metabolism, reproductive maturation }\end{array}$} \\
\hline shrimp & $28 d$ & & \\
\hline sheepshead minnow & $5 d$ & - & VTG mRNA, estrogen receptor mRNA (RNA from liver) \\
\hline Palaemonetes pugio & until maturation & water & survival, morting, development stage \\
\hline Rhithropanopeus harrisii & until maturation & water & survival, morting, development stage \\
\hline \multirow{2}{*}{ Oryzias latipes } & $3 \mathrm{~h}$ (in vitro) & \multirow{2}{*}{ water } & \multirow{2}{*}{ brain aromatase activity } \\
\hline & $10 \mathrm{~d}$ (in vivo) & & \\
\hline Oreochromis mossambicus & $28 d$ & water & sex ratio, body weight, liver weight, gonad weight, pituitary weight \\
\hline Tetrahymena pyriformis & $8 \mathrm{~h}$ & water & growth \\
\hline \multirow{2}{*}{ Callinectes sapidus embryo } & $2-6 d$ & water & hatching \\
\hline & $24 \mathrm{~h}$ & water & DNA damage \\
\hline Orconectes rusticus & $7 d$ & water & survival, swimming behaviour \\
\hline Oncorhynchus mykiss & $96 \mathrm{~h}$ & water & swimming behaviour, protein content, cholinesterase activity \\
\hline \multirow{2}{*}{ Lepomis macrochirus } & $30 \mathrm{~d}$ & \multirow{2}{*}{ water } & survival, growth, swimming capacity, strike frequency, feeding efficiency, aggression \\
\hline & $56 \mathrm{~d}$ & & survival, growth, biomass, reproduction \\
\hline \multirow{3}{*}{ Oreochromis niloticus } & until dead & \multirow{3}{*}{ water } & \multirow{3}{*}{ survival, uptake } \\
\hline & 4 months & & \\
\hline & 7 months & & \\
\hline Lampsilis straminea claibomensis & $9 d$ & sediment & survival \\
\hline Caenorhabditis elegans & $24 \mathrm{~h}$ & soil & survival, recovery \\
\hline
\end{tabular}

지질, 스테로이드 호르몬, 성숙 등을 독성종말점으로 제시 하였다. 원생동물인 Tetrahymena pyriformis를 이용한 독성 평가는 8 시간 노출 후 성장을 평가하였다.

해양동물을 이용한 독성기법은 2건으로 새우류 Palaemonetes pugio와 게류 Rhithropanopeus harrisii를 이용한 만성독성 기법으로 개체 성숙까지 노출하였으며 독성종말점은 생존, 탈피, 발달단계를 평가하였다. 다른 한 건은 게의 수정란을 이용한 독성평가로 embryo를 2-6일 노출 후 부화율을 평가 하였고 $24 \mathrm{~h}$ 노출 후 DNA 손상을 평가하였다.

또한 퇴적물 독성평가는 패류인 Lampsilis straminea claibo$m e n s i s$ 를 이용하여 9일 노출 후 개체의 생존을 평가하였고, 토양매체에서의 독성평가는 토양선충 Caenorhabditis elegans 를 이용하여 24시간 노출하였으며 생존을 독성종말점으로 사용하였다.

\subsection{USEPA}

미국 환경보호국(USEPA)에서는 EDCs 독성평가를 위한 실험 법을 제공하고 있으며, 이는 유해물질규제법(toxic substances control act, TSCA), 살충 - 살균 - 살서제법(insecticide, fungicide, and rodenticide act, FIFRA), 및 연방식품의약품화장품법 (federal food, drug, and cosmetic act, FFDCA)에 따른 데이터 를 제공하기 위해 USEPA 소속의 예방농약유독물질실 (office of prevention, pesticides and toxic substances, OPPTS)과 화학 물질안전/오염방지실(office of chemical safety and pollution prevention, OCSPP) 에서 만들어졌다. ${ }^{42)}$

USEPA에서 시행하고 있는 내분비계장애물질 스크리닝 프 로그램(endocrine disrupter screening program, EDSP)에서는 FFDCA section 408 (21 U.S.C. 346a)에 명시된 바에 따라 실 험 가이드라인을 Tier 1 과 Tier 2 로 나누어 제시하고 있다. ${ }^{43)}$ Tier 1 스크리닝은 OPPTS 890 Series의 가이드라인을 통해 full-screening battery를 진행하고, 대상물질이 에스트로겐, 안드로겐, 및 갑상선 호르몬에 영향을 줄 수 있는 가능성을 확인한다. 그러나 대상물질이 호르몬 시스템에 영향을 미치 는지 까지만 확인 할 수 있으며, 인간이나 환경에 내분비계 장애물질로써 작용하는지는 확인할 수 없다. Tier 1 스크리 닝의 결과는 추가적인 과학적 정보와 함께 비교하고, 이를 토대로 Tier 2 시험의 진행여부를 결정하게 된다. Tier 2 시 험은 OCSPP 890 Series에서 총 3건의 가이드라인을 제시 하고 있으며, 이를 통해 대상 물질이 내분비계 장애물질로 악영향에 관여되는지 판단 할 수 있다. 또한, 대상물질로 발 생한 악영향과 대상물질의 농도간의 용량-반응 관계를 알아 낼 수 있다.

Tier 1 스크리닝은 총 11 건의 가이드라인이 존재하며, 대상 시험종으로 양서류, 어류, 인간 세포주 렛트 그리고 렛트에 서 추출한 효소를 이용한 실험법을 제시하고 있다. ${ }^{43)}$ 이 중 양서류 변태과정과 어류 생식능 평가를 이용한 단 2건만이 생태독성평가 실험법에 해당한다(Table 3). OPPTS 890.1100 (USEPA, 2009a)에서는 양서류인 Xenopus laevis의 올챙이 를 이용하여 변태 간에 발생할 수 있는 형태학적 이상을 스 크리닝 할 수 있는 방법을 제시하였다. 20 마리의 올챙이를 1 일간 유수식 $(25 \mathrm{ml} /$ 분 $)$ 으로 노출하였으며, 노출 조건은 22 ${ }^{\circ} \mathrm{C}, 12 \mathrm{~h}$ light: $12 \mathrm{~h}$ dark (600-2000 lux)이었다. 내분비계 장 
Table 3. EDCs specific ecotoxicity test guidelines and test conditions in USEPA

\begin{tabular}{|c|c|c|c|c|c|c|c|}
\hline Tier & Species & Test duration & Media & Temperature & Light & Endpoint & Ref. \\
\hline \multirow{2}{*}{ Teir 1} & Xenopus laevis & $21 d$ & $\begin{array}{l}\text { any water that is } \\
\text { locally available }\end{array}$ & $22 \pm 1^{\circ} \mathrm{C}$ & $\begin{array}{c}12 \text { h light: } \\
12 \text { h dark } \\
\text { (600 to } 2000 \text { lux) }\end{array}$ & $\begin{array}{l}\text { limb length, snout to vent length, } \\
\text { developmental stage, wet weight, } \\
\text { thyroid histology }\end{array}$ & 42 \\
\hline & $\begin{array}{l}\text { Pimephales } \\
\text { promela }\end{array}$ & $21 d$ & $\begin{array}{l}\text { clean, surface, well, } \\
\text { or reconstituted } \\
\text { water }\end{array}$ & $25 \pm 1^{\circ} \mathrm{C}$ & $\begin{array}{c}16 \text { h light: } \\
8 \text { h dark } \\
\text { (540 to } 1080 \text { lux) }\end{array}$ & $\begin{array}{l}\text { survival, reproductive behavior, } \\
\text { secondary sex, fecundity, fertility }\end{array}$ & 44 \\
\hline \multirow{2}{*}{ Teir 2} & Oryzias latipes & $19 w$ & $\begin{array}{l}\text { any water that is } \\
\text { suitable long-term } \\
\text { survival and growth }\end{array}$ & $25 \pm 1^{\circ} \mathrm{C}$ & $\begin{array}{c}16 \text { h light: } \\
8 \text { h dark } \\
\text { (100 to } 150 \text { lux })\end{array}$ & $\begin{array}{l}\text { survial, growth, vitellogenin, } \\
\text { secondary sex, histopathology, } \\
\text { fecundity, fertility }\end{array}$ & 45 \\
\hline & Xenopus laevis & $10 w$ & $\begin{array}{l}\text { any water that is } \\
\text { locally available }\end{array}$ & $21 \pm 1^{\circ} \mathrm{C}$ & $\begin{array}{c}12 \text { h light: } \\
12 \text { h dark } \\
\text { (600 to } 2000 \text { lux) }\end{array}$ & $\begin{array}{l}\text { survial, abnormal behavior, } \\
\text { abnormal morphology, } \\
\text { length, weight }\end{array}$ & 46 \\
\hline
\end{tabular}

애물질로 인하여 영향이 발생하는 생존률, 성장단계, 뒷다리 길이, 몸통길이, 생체량, 갑상선 조직학적 이상으로 총 6 가 지의 종말점을 제시하고 있으며 생존률은 매일, 형태학적 종말점(길이, 무게)은 7 일과 12 일, 및 갑상선 조직학적 이상 은 21일에 한 번씩 측정하도록 하였다. OPPTS $890.1350^{44)}$ 에서는 어류인 Pimephales promelas를 이용하여 발생하는 생존률, 생식률 및 다양한 생식기관의 이상을 관찰 할 수 있 는 방법을 제시하였다. 4-6달 된 4마리의 암컷, 2 마리의 수컷 P. promelas를 유수식 $(2.7 \mathrm{~L} /$ 시간 $)$ 으로 노출하며, 노출 조건 은 $25^{\circ} \mathrm{C}, 16 \mathrm{~h}$ light: $8 \mathrm{~h}$ dark (540-1080 lux)으로 하였다. 생존률, 생식률, 이상 거동, 및 알 생산(Fecundity)은 매일 측 정하였으며, 수정률, 성체의 형태학적 이상, 성체의 무게 및 길이는 노출이 종료된 시점에 측정하였다. 노출 종료 후 노 출 개체를 회수 하여 vitellogenin의 농도, 성 호르몬농도, 2 차 성징 및 생식샘 이상을 측정하도록 하였다. 특히 생식샘 이상의 경우 현미경 관찰에서 확인 할 수 있는 이상 현상 을 정상개체, 수컷, 암컷, 및 기타 이상 징후로 나누어 현미 경 관찰사진으로 제시하였다.

Tier 2 시험법은 총 3 건의 가이드라인이 존재하며, 대상 시험종으로 메추라기, 어류, 양서류를 이용한 시험법을 제시 하고 있다. Tier 1 스크리닝에서 보다 오랜 기간 동안 노출 후 독성을 평가 한다.

OCSPP $890.2200^{45}$ 에서는 어류인 Oryzias latipes를 이용하 여 어미세대에서 후세대까지 수정, 부화, 치어, 성체, 및 생 식에 이르는 종말점을 모두 평가할 수 있는 실험법을 제시 하였다. 반복별 1 쌍의 교배 쌍(F0)을 유수식으로 노출하였 고, 반복 당 20 개의 수정란(F1) 14 주간 노출시켰다. 노출 조 건은 $25^{\circ} \mathrm{C}, 16 \mathrm{~h}$ light: $8 \mathrm{~h}$ dark (100-150 lux)으로 하였다. 어미세대(F0)에 노출 후 첫 3 주동안 $\mathrm{F} 0$ 의 알 생산량과 수 정률을 평가하였으며, 4 주차에는 $\mathrm{F} 0$ 의 성장률을 평가하였 다. 5 주차(수정 후 2 주차)에는 $\mathrm{F} 1$ 의 부화율과 6 주차에는 치 어(F1)의 생존률을 평가하였다. 12 주차에 $\mathrm{F} 1$ 의 생존률, 성장 률, vitellogenin 및 2차 성징을 평가하였고, 15-17주차에는 $\mathrm{F} 1$ 의 알 생산량 및 수정률을 평가하였으며, 18 주차(수정 후 14주)에 F1의 생존률, 성장률, 2 차 성징 및 생식소 및 장기 의 조직 병리학적 이상을 현미경으로 관찰하였다. 마지막
으로 19주차에 F2의 부화율을 측정하도록 하여 한 생식주 기 동안 발생하는 이상현상을 관찰 할 수 있도록 하였다. OCSPP $890.2300^{46}$ 에서는 양서류인 Xenopus laevis를 이용 하여 올챙이에서 성체까지 다양한 종말점을 평가할 수 있는 실험법을 제시하였다. 반복별 Nieuwkoop and Faber (NF) stage 8-10의 X. laevis를 20 개체 씩 노출하여 매일 생존율 및 병리 학적 이상을 확인하였다. NF stage 62 (노출 후 약 41일 후) 갑상선의 조직병리학적 이상, 길이 및 무게를 측정하였다. $\mathrm{NF}$ stage 66(노출 후 약 70일 후)에 도달한 개체를 임의로 10 개체를 선발 한 뒤 16 주 까지 노출하였다. 노출 종료 후 길이, 무게, liver-somatic 지수, 유전학적 성비, 생식기관 및 내장 기관의 조직병리학적 이상을 측정하도록 하여 OCSPP 890.2200 (USEPA, 2015a)에서와 마찬가지로 대상 생물종의 한 생식주기 동안 발생하는 이상 현상을 관찰 할 수 있도 록 하였으며, Tier 1 스크리닝 수준에서 보다 충분한 실험 결과를 바탕으로 내분비계장애물질이 개체에 어떠한 악영향 을 미치는지 예측 할 수 있도록 하였다. 현재 USEPA에서 제공하는 EDCs를 위한 생태독성시험법은 Tier 1에서 2건, Tier 2에서 2건이며 모두 수서 생태종을 이용한 시험법이다. 현재까지는 토양생태 시험종에 대한 시험법은 제시되고 있 지 않고 있다.

\subsection{ISO}

현재까지 국제표준화기구(ISO)에서는 기존의 생태독성기 법, 독성종말점 이외에 $\mathrm{EDCs}$ 에 대한 생태독성기법과 독성 종말점을 제안하고 있지 않는 것으로 확인되었다.

\section{4. 결 론}

국외 $\mathrm{EDCs}$ 관련 생태독성기법을 조사한 결과, 수서생물종 은 어류 양서류, 물벼룩 및 요각류, 토양생물종은 애지렁이, 지렁이, 톡토기 및 토양선충, 그리고 퇴적물서식 생물종은 깔따구와 지렁이에 대해 기법이 개발되거나 기존 일반물질 에 대한 기법을 그대로 적용 가능한 것으로 확인한 문서들 이 보고되었다. 어류의 경우 androgen, estrogen, thyroid hor- 
mone, diagnosis, sexual development, diagnosis of gonads, reproduction에 대한 종말점을, 양서류의 경우 metamorphosis, histology, growth, development에 대한 종말점을, 요각류의 경우 development 및 생식에 대한 종말점을, 물벼룩의 경우 생식에 대한 종말점을, 지렁이 종의 경우 생존, 성장 및 생 식에 대한 종말점을, 깔따구의 경우 암수컷 개체출현, 성비, 생존율, 거동, 생식에 대한 종말점을, 진드기와 톡토기의 경 우 생존율 및 생식에 대한 종말점, 그리고 토양선충의 경우 생식에 대한 종말점을 평가하고 있었다. $\mathrm{EDCs}$ 에 의한 생 태독성을 평가할 수 있는 종말점으로서 수서, 토양, 퇴적물 생물종에서 공통적으로 생식이 제안되어 있었으며, 어류와 양서류는 호르몬과 관련된 종말점들을 평가할 수 있는 기 법이 마련되어 있는 상태이다. 한편 수서생태독성기법과 달 리 $\mathrm{EDCs}$ 에 대한 토양생태독성기법은 현재까지 몇가지 $\mathrm{TG}$ 에 대해 기존의 $\mathrm{TG}$ 를 그대로 적용 가능함을 확인한 것으로 써 $\mathrm{EDCs}$ 특이적인 $\mathrm{TG}$ 로 개발된 것은 없었다. 따라서 향후 국내뿐만 아니라 국외에서도 EDCs에 대한 토양생태독성기 법은 다양한 생물종에 대해 개발이 되어야 할 필요성이 있 는 것으로 분석되었다.

\section{Acknowledgement}

이 연구는 환경부 “생활공감 환경보건기술개발사업(EDCs 통합위해관리를 위한 한국형 환경 및 생태유해성 평가 기술 개발)" 및 한국연구재단(NRF-2016R1A2B3010445) 지원을 받아 수행되었음.

KSEE

\section{Reference}

1. Ministry of Environment, Handbook of Environmental Science (II)(1999).

2. An, Y.-J., Nam, S.-H. and Lee, J.-K., "Categorization of hazard chemicals potentially discharged into water system," J. Korean Soc. Water Environ., 24, 247 259(2008).

3. Ministry of Environment, Study on endocrine discruptors (VI) (2005).

4. Ministry of Environment and National Institute of Environmental Research, Development of integrated methodology for evaluation of water environment (III)(2006).

5. Ministry of Environment, 2014 Pollutant Release and Transfer data, http://ncis.nier.go.kr/tri/(2017)

6. Ministry of Environment, Water information system, http:// water.nier.go.kr/main/mainContent.do(2017).

7. Ministry of Environment, Action plan for water monitoring. (2016).

8. Organization for Economic Cooperation and Development (OECD), OECD work related to endocrine disrupters, http:// www.oecd.org/env/ehs/testing/oecdworkrelatedtoendocrinedisru pters.htm(2016).
9. Organization for Economic Cooperation and Development (OECD), "Series on testing and assessment No. 150 Guidance document on standardised test guidelines for evaluating chemicals for endocrine disruption," (2012).

10. Organization for Economic Cooperation and Development (OECD), "Work plan for the test guidelines programme (TGP)," (2016).

11. Organization for Economic Cooperation and Development (OECD), "Series on testing and assessment No. 95 Detailed review paper on fish life-cycle tests," (2008).

12. Organization for Economic Cooperation and Development (OECD), "Series on testing and assessment No. 127 Peer review report of the validation of the 21-day androgenised female stickleback screening assay," (2011).

13. Organization for Economic Cooperation and Development (OECD), "Series on testing and assessment No. 128 Validation report on the 21-day androgenised female stickleback screening assay," (2010).

14. Organization for Economic Cooperation and Development (OECD), "Series on testing and assessment No. 148 Guidance document on the androgenised female stickleback screen," (2011).

15. Organization for Economic Cooperation and Development (OECD), "Work plan for the test guidelines programme (TGP)," (2015)

16. Organization for Economic Cooperation and Development (OECD), "Series on testing and assessment No. 158 Report of progress on the interlaboratory validation of the OECD harpacticoid copepod development and reproduction test," (2011).

17. Organization for Economic Cooperation and Development (OECD), "Series on testing and assessment No. 201 New guidance document on harpacticoid copepod development and reproduction sest with amphiascus," (2011).

18. Organization for Economic Cooperation and Development (OECD), Series on testing and assessment: Testing for endocrine disrupters, http://www.oecd.org/chemicalsafety/testing/ seriesontestingandassessmenttestingforendocrinedisrupters.htm (2016).

19. Organization for Economic Cooperation and Development (OECD), "Guideline for testing of chemicals 229 Fish short term reproduction assay," (2012).

20. Organization for Economic Cooperation and Development (OECD), "Guideline for testing of chemicals 230 21-day fish assay: A short-term screening for oestrogenic and androgenic activity, and aromatase inhibition," (2009).

21. Organization for Economic Cooperation and Development (OECD), "Guideline for testing of chemicals 234 Fish sexual development test," (2011).

22. Organization for Economic Cooperation and Development (OECD), "Guideline for testing of chemicals 240 Medaka extended one generation reproduction test (MEOGRT)," (2015).

23. Organization for Economic Cooperation and Development (OECD), "Guideline for testing of chemicals 231 The amphibian metamorphosis assay," (2009).

24. Organization for Economic Cooperation and Development 
(OECD), "Guideline for testing of chemicals 241 The larval amphibian growth and development assay (LAGDA)," (2015).

25. Organization for Economic Cooperation and Development (OECD), "Series on testing and assessment No. 76 Final report of the validation of the amphibian metamorphosis assay for the detection of thyroid Active susbstances - Phase 1: Optimisation of the test protocol," (2007).

26. Organization for Economic Cooperation and Development (OECD), "Series on testing and assessment No. 77 Final report of the validation of the amphibian metamorphosis assay - Phase 2: Multi-chemical interlaboratory study," (2007).

27. Organization for Economic Cooperation and Development (OECD), "Series on testing and assessment No. 91 Report of the validation of the amphibian metamorphosis assay (phase 3)," (2008).

28. Organization for Economic Cooperation and Development (OECD), "Series on testing and assessment No. 92 Report of the validation peer review for the amphibian metamophosis assay and agreement of the working group of the national coordinators of the test guidelines programme on the follow-up of this report," (2008).

29. Organization for Economic Cooperation and Development (OECD), "Guideline for testing of chemicals 211 Daphnia magna reproduction test," (2012).

30. Organization for Economic Cooperation and Development (OECD), "Series on testing and assessment No. 93 Report of the validation of an enhancement of OECD TG 211: Daphnia magna reproduction test," (2008).

31. Organization for Economic Cooperation and Development (OECD), "Guideline for testing of chemicals 220 Enchytraeid reproduction test," (2004).

32. Organization for Economic Cooperation and Development (OECD), "Guideline for testing of chemicals 222 Earthworm reproduction test (Eisenia fetida / Eisenia andrei)," (2004).

33. Organization for Economic Cooperation and Development (OECD), "Guideline for testing of chemicals 226 Predatory mite (Hypoaspis (Geolaelaps) aculeifer) reproduction test in soil," (2008).

34. Organization for Economic Cooperation and Development (OECD), "Guideline for testing of chemicals 232 Collembolan reproduction test in soil," (2009).

35. Organization for Economic Cooperation and Development
(OECD), "Guideline for testing of chemicals 218 Sedimentwater chironomid toxicity test using spiked sediment," (2004).

36. Organization for Economic Cooperation and Development (OECD), "Guideline for testing of chemicals 219 Sedimentwater chironomid toxicity test using spiked water," (2004).

37. Organization for Economic Cooperation and Development (OECD), "Guideline for testing of chemicals 233 Sedimentwater chironomid life-cycle toxicity test using spiked water or spiked sediment," (2010).

38. Organization for Economic Cooperation and Development (OECD), "Guideline for testing of chemicals 225 Sedimentwater Lumbriculus toxicity test using spiked sediment," (2007).

39. American Society for Testing and Materials (ASTM), "STP 1364 Environmental toxicology and risk assessment: Standardization of biomarkers for endocrine disruption and environmental assessment: 8th volume," (1999).

40. American Society for Testing and Materials (ASTM), “ASTM Standard E-1193-87: Standard practice for conducting renewal life-cycle toxicity tests with Daphnia magna," (1987).

41. American Society for Testing and Materials (ASTM), ASTM Standard E-1191-90: Standard guide for conducting life-cycle toxicity test with saltwater mysids, (1990).

42. United States Environmental Protection Agency (USEPA), "Endocrine Disruptor Screening Program Test Guidelines OPPTS 890.1100: Amphibian Metamorphosis (Frog)," (2009a).

43. United States Environmental Protection Agency (USEPA), "Series 890 - Endocrine Disruptor Screening Program Test Guidelines," https://www.epa.gov/test-guidelines-pesticides-andtoxic-substances/series-890-endocrine-disruptor-screening-pro gram, (2016.08).

44. United States Environmental Protection Agency (USEPA), "Endocrine Disruptor Screening Program Test Guidelines OPPTS 890.1350: Fish Short-Term Reproduction Assay," (2009b).

45. United States Environmental Protection Agency (USEPA), "Endocrine Disruptor Screening Program Test Guidelines OCSPP 890.2200: Medaka Extended One Generation Reproduction Test (MEOGRT)," (2015a).

46. United States Environmental Protection Agency (USEPA), "Endocrine Disruptor Screening Program Test Guidelines OCSPP 890.2300: Larval Amphibian Growth and Development Assay (LAGDA)," (2015b). 